\title{
How trust was maintained in Scandinavia through the first crisis of modernity
}

Historical accounts for trust in Scandinavia

Øystein Pedersen Dahlen

School of Communication, Leadership and Marketing, Kristiania University College, Oslo, Norway, and

Helge Skirbekk

Department of Health Management and Health Economics, University of Oslo, Oslo, Norway

\begin{abstract}
Purpose - The aim of this article is to explain why there is a higher degree of trust in some countries compared to others - and which are the main historical factors that explain these differences. The main focus is on how governments relate to and communicate with its citizens in the times of crises.

Design/methodology/approach - The analysis is based on comparative historical sociology with a modernity perspective with a special focus on Norway and Scandinavia. The authors do a parallel demonstration of history to confirm and expand the theories that could explain the high level of trust in these countries. The authors also bring in the Spanish experience in order to testify how governmental reactions affected the different levels of trust.

Findings - Scandinavian governments allowed open communication between different social classes on difficult and important issues, in contrast to Spain in the same period. These two factors therefore expand the understanding of the development of trust: (1) The establishment of the nation state as the organising concept and all-encompassing container of the other institutions (democracy, parliamentarism, trade unions, etc.); (2) The open hand strategy in dealing with deviant opinions, based on democratic compromises and a policing of consent ideology.

Originality/value - The article combines the understanding of the first crisis of modernity and the development of trust and contain a comparative analysis of the development of trust in four different countries. The investigation thus clarifies the correlation between specific historical factors and the levels of trust.
\end{abstract}

Keywords Scandinavia, Spain, Norway, Trust, Comparative historical sociology, First crisis of modernity Paper type Research paper

\section{Introduction}

The end of the 19th century signalled a turning point and a crossroads for the development of modernity in Europe. The early 20th century was a period of conflicts and divisions in most European countries, triggered by increasing nationalism and class struggle. The analysis in this article will focus on the way in which the conflicts in the first crisis of modernity (cf. Wagner, 1994) were handled and how these reactions influenced the level of trust, with a special focus on Scandinavia.

Trust is the basis for all communication, facilitating co-operation and communication amongst people in any society (Tschannen-Moran and Hoy, 2000). Trust can therefore be regarded as one of the most crucial concepts of public relations (Ihlen and Verhoeven, 2012, p. 170). To be trusted can both be a means and an end for public relations (Ihlen et al., 2018, p. 422). At the same time,

(C) Øystein Pedersen Dahlen and Helge Skirbekk. Published by Emerald Publishing Limited. This article is published under the Creative Commons Attribution (CC BY 4.0) licence. Anyone may reproduce, distribute, translate and create derivative works of this article (for both commercial and non-commercial purposes), subject to full attribution to the original publication and authors. The full terms of this licence may be seen at http://creativecommons.org/licences/by/4.0/legalcode

Received 31 January 2020 Revised 13 July 2020 Accepted 8 September 2020

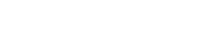

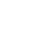

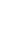


CCIJ

26,1

democracy requires a certain type of scepticism towards politics, such as when the public assesses the views and actions of politicians (Inglehart, 1999), and democratic processes are the most important guarantor of social integration in modern society (Habermas, 1998).

In this article, we attempt to outline some explanations for the high level of trust in Scandinavia (Norway, Sweden and Denmark), related to political participation and democracy in the period from 1890 to 1935 . The Scandinavian countries have been chosen for their high degree of trust, while we choose Spain as a comparison for its relatively low degree of trust (European Social Survey [1]; World Values Survey [2]). We suggest that the new challenges of the first crisis of modernity threatened the credibility of the authorities and could very well undermine the trust between the governments and their citizens. The Spanish civil war from 1936 clearly exemplifies a lack of trust. At the same time, the Scandinavian countries were establishing social democratic or social liberal welfare states, indicating high levels of trust.

Most historical research on trust in Scandinavia has focussed on the popular, democratic development in Norway (and Sweden) in the 1800s, without comparisons to other countries. We will analyse the relationship between the governments and their citizens, with a special focus on communication efforts and conflict resolution and how the crisis was handled by the governments.

Our principal research question is the following:

How can governmental reactions to the first crisis of modernity explain the different levels of trust today?

To be able to answer the main question, we will ask three sub-questions:

(1) What are the main historical factors, related to the reactions to public complaints and deviating opinions during the first crisis of modernity, that can explain the high level of trust in Scandinavia?

(2) What are the main historical factors, related to reactions to public complaints and deviating opinions during the first crisis of modernity, that can explain the relative low level of trust in Spain?

(3) How can governmental conflict resolution during the first crisis of modernity support and expand our understanding of the level of institutional and social trust?

\section{Methodological and theoretical premises}

The analytic approach in this article is comparative historical sociology with a modernity perspective. A modernity perspective can provide a vertical view of the various dimensions of societies, such as democracy, economy and politics. Modernity is also a universal topic which makes it possible to analyse the development of PR and society in a global context (Hu et al., 2015, p. 263; Dahlen, 2019), and thus to compare different nations. We will do a comparative historical analysis of the Scandinavian development as a parallel demonstration of history (cf. Skocpol and Somers, 1980, p. 176) to confirm and expand the theories that could explain the high level of trust in these countries. We will also use the contrast of context (cf. Skocpol and Somers, 1980, p. 178) to bring in the Spanish experience, in order to testify how governmental reactions affected the different levels of trust. In line with the tradition of comparative historical sociology, we will use the work of historians to serve our sociological end (cf. Delanty and Isin, 2003, p. 3).

The first crisis of modernity is of special interest when analysing trust, due to the disembedding of the social and national institutions "of giant scale" (Wagner, 2001, p. 84). These crises led to reconstructions of social institutions, and therefore radical change in these social conventions (Wagner, 2012). The governments' reactions to the most visible protests 
and divergent opinions during the first crisis of modernity are analysed, in order to get an understanding of the role of governmental reactions and relations to the public.

The understanding of public relations in this article is in line with what Lamme and Russell (2009, p. 335) call the strategic intent to work for profit (including fund raising), recruitment (including volunteers), legitimacy, agitation, advocacy and to reduce fear (Russel and Lamme, 2013). Three elementary principles of public relation should still be in place: (1) public attention, (2) competition in society and (3) a public sphere. These principles point to certain social conditions (Bentele, 2015, p. 29) and are normally part of a modern society. PR activities are further associated with: (1) formal institutions (the state, business and civil society), (2) public debate and (3) opportunities to exert influence. In keeping with L'Etang's (2008) proposition on writing PR history, the outline of this article is centred around "larger processes of transformation" (p. 321), as well as power relations between dominant and subordinated groups (Edwards, 2018, p. 6).

The first crisis of modernity is a significant period in the theory of the successive modernities by Peter Wagner $(1994,2012)$, where this first crisis is a reaction to the liberal modernity of the 1800s. A new era, which follows a crisis, solves some of the problems that existed in the previous era, but new challenges inevitably emerge. Wagner's analysis is in many ways a critique of evolutionary modernisation theories and the belief in general progresses from a universal perspective. The theory creates a more dynamic and actororiented understanding of the historical evolution of the modern - while developing a contemporary diagnosis for the turn of the century. The first crisis of modernity is followed by organised modernity from the 1920s and later replaced by today's liberal, global network capitalism of the 1970s (Wagner, 1994, 2001, 2012).

In the context of the development of European modernity, where autonomy and selfdetermination are political values, "institutions are in need for justification, of a justificatory discourse" (Wagner, 2003, p. 177), as the nation state as institution needs to be legitimized to gain public support - and trust. Modern nation states are legitimised through national democratic processes, where the addressees of laws also are the authors of the same laws (Habermas, 1996, p. 123). The citizens will feel strongly socially committed, thus maintaining social integration. And without a historical constructed community, it is difficult to mobilise for collective action (Ellefsen and Larsson, 2014, p. 32). Wagner (1994, p. 7) claims, however, that the nation state is first and foremost an instrument to restrict practices and discipline individuals. Therefore, Wagner (1994, p. 21) believes that the most important challenge in Western societies is to understand the role of government between power and individual liberty, to analyse the nation state as a mechanism for both individualisation and totalisation.

In keeping with Wagner's $(2012,2008)$ theory on successive modernities, we will analyse the relationship between capitalism and democracy, the relationship between class and nation as organising principles, and how the workers tried to find their social position in the new social order in the organised modernity. We will present for each country shortly: (1) the situation in 1890, (2) the signs of the first crisis of modernity, (3) the authorities' reactions to the protests and deviating opinions and (4) the new organisation of societies, in the organised modernity - and then analyse how the re-organised institutions could built trust. Institutions are here defined as relatively stable social conventions (cf. Wagner, 1994).

The literature on trust has been reviewed mostly through snowballing: reading the most relevant articles in the literature lists of already known research on our subject. We have also done library searches on the terms trust, political trust, general social trust, and trust and political crisis, in our given historical time frame and for the countries we wished to compare. Some results were found for the Scandinavian countries, but less related to Spain in the current time period. We have used historical trust levels as a measurement.

In the present time, finding trust levels is unproblematic. The European Social Survey, the World Values Survey, and others, regularly publish such statistics. But it is of course more

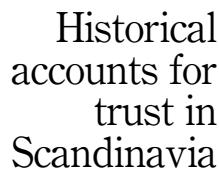


CCIJ

26,1

problematic for our historical time frame, since trust surveys were not performed before the Second World War. We have therefore taken advantage of some studies with innovative ways of measuring trust relevant for our time frame. Bergh and Bjørnskov (2011) have studied trust levels in 77 countries using three instruments: the grammatical rule allowing pronoun-drop, average temperature in the coldest month and a dummy for constitutional monarchies. They then compared current welfare state size and found that high-trust countries were able to finance higher total government expenditures, and that high-trust countries are characterised by fewer market regulations. Algan and Cahuc (2010) developed a new method to uncover the causal effect of trust on economic growth by focussing on the inherited component of trust and its time variation. They showed that inherited trust of descendants of US immigrants is significantly influenced by the country of origin and the timing of arrival of their forebears. They could therefore use the inherited trust of descendants of US immigrants as a time-varying measure of inherited trust in their country of origin. Relevant literature on trust is presented in the next section.

\section{Trust in institutions}

Trust influences how we understand and perceive information, and it creates a more positive understanding of the sender and the message (Skirbekk et al., 2011; Skirbekk and Skirbekk, 2012). Without trust, all communication and reception of information will suffer and be subject to uncertainty and/or scrutiny. Trust may be described as having belief in the character of a person, the quality of an organisation or the truth of a statement (Giddens, 1990). In a relationship based on trust, people tend to take fewer precautions, and are less worried about what can go wrong. Consequently, we wish to have trust in others when the decisions they reach are important to us (Grimen, 2009). Trust is therefore crucial in most situations where we interact with others and something important is at stake (Gambetta, 1988, p. xi).

A high level of trust is often robust, and general social trust can be inherited and evolve over long periods, in the sense that it persists over decades within specific countries and cultures (Putnam, 2000; Inglehart, 1999; Algan and Cahuc, 2010). General social trust stands in contrast to particularised trust, where people have faith only in a limited group of the same ethnicity, religion, class, clan or family (Rothstein and Uslaner, 2005 , p. 45). There is also a robust and significant relationship between general social trust and trust in state institutions, such as the police and the judicial system (Sönderskov and Dinesen, 2016).

Algan and Cahuc (2010) found strong correlations between the levels of trust in the country of origin of the descendants of immigrants to the United States, and the current levels amongst the descendants of immigrants. Those with Nordic (and Dutch) origins exhibit the most trusting attitudes, comparable to the high levels of general social trust in Scandinavian countries today (shown in updated cross-national surveys). The descendants of immigrants from Central and Western Europe tend to have less trust, while those with Eastern and Southern European backgrounds have the lowest level of general social trust. This is also in line with current surveys of trust levels in European countries (Algan and Cahuc, 2010), as well as other research (Putnam, 2000; Inglehart, 1999; Rothstein and Uslaner, 2005; Skirbekk and Skirbekk, 2012).

Corruption weakens the belief that conflicts can be resolved, and that criminal acts involving corruption will be punished. In a society characterised by corruption, one becomes more cautious when dealing with other people. Further, economic and cultural equality is also correlated with a high level of trust. There is also a correlation between political and bureaucratic transparency and the level of trust in governments. Corruption is one of the main factors that contributes to creating mistrust towards political and administrative institutions and their executives (Rothstein, 2013). 
Consequently, there are various established explanations regarding what creates trust in a specific culture or nation, which could be summed up in four points (Rothstein, 2013; Rothstein and Uslaner, 2005; Skirbekk and Skirbekk, 2012; Wollebæk, 2016; and others):

(1) There should be a fair legal system and as little corruption as possible.

(2) There should be relative equality amongst the members of society: both economically, but more importantly, there should also be a sense of common norms and values. This also leads to the next explanation.

(3) There should be a common perception of destiny, both historically and for the future. This includes perceptions of what constitutes facts and challenges.

(4) There should be continuous interaction between the members of a society, and an active and respected civil society that is able to exert influence. This also means that there should be the possibility of having dialogues on difficult and important issues through open decision-making processes.

In the Scandinavian countries, there is a persistently higher degree of trust than in any other country in the world, measured both as trust in institutions and in others (general social trust) (ESS, WVS), whereas in countries in Southern Europe, there is a lower degree of trust. (Putnam, 2000; Inglehart, 1999; Algan and Cahuc, 2010; Rothstein and Uslaner, 2005; Skirbekk and Skirbekk, 2012). Since the level of trust persists over decades, the common idea that the high level of trust in Scandinavia can be explained by the welfare state in Scandinavia can be refuted (Wollebæk, 2016; Bergh and Bjørnskov, 2011). It could rather be explained by the development over centuries and could partly have to do with the existence of peace, stability and a relatively fair justice system (Skirbekk and Skirbekk, 2012, p. 59).

\section{Development of high trust in Scandinavia in the 19th century}

From the turn of the 18th century in Scandinavia, civil organisations were established, and many social reforms were developed towards the end of the 1800s. The modernisation processes in the 1800s - meaning the establishment of such national institutions as democracy, parliamentarism, bureaucracy and the juridical system - were mainly based on popular movements, leading to trustful relationships between the civil society and these institutions.

The Scandinavian democracies were partly based on bottom-up developments, through popular movements and partly top-down developments of modern reformers, resulting in integration within the populations and consolidation of the respective nations. The emergence of popular movements during the early 18th and late 19th century, especially the workers', farmers' and Christian lay organisations, not only contributed to the spread of literacy but also demonstrated to the ruling class that they were capable of negotiation without resorting to violent rebellions (Skirbekk and Skirbekk, 2012). They therefore laid an important groundwork for peaceful debates with the established bourgeois government.

In Norway, Christian lay organisations helped spread literacy amongst the farmers and workers from the late 18th century. In 1814, after the Napoleonic wars, Norway gained a constitution that was considered relatively liberal for its time, guaranteeing liberal freedoms of speech and organisation. Workers' and farmers' rights spread during the middle of the 19th century. Male citizens over 25 with a relatively high income were eligible to vote for parliament. By the late 19th century, these movements had gained control over the Norwegian Parliament, and in 1884, they gained control of the government. This bottom-up development of modernity and the social movements were of great importance in establishing trust in the government and the legitimacy of the rule of law in Scandinavia (Skirbekk and Skirbekk, 2012; Trägårdh et al., 2013). 
CCIJ

26,1

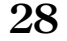

Even if the welfare system should not be understood as the main explanation for trust in Scandinavia, the development of the welfare system in the 20th century reduced the sense of risk in the population, so that less was at stake when people chose to trust others. And the trust in the all-encompassing nation states to build expanding welfare states testifies that there was a high degree of trust in the governments, before the development of welfare states began (Wollebæk, 2016). Throughout the course of the 20th century, the power of the sovereign states was limited by the liberal judicial system, which is characterised by the protection of the individual (Sejersted, 2013, p. 22). This liberal limitation of state power in Scandinavia can explain the continued strong and persistent trust in government and the established social institutions. In summary, favourable historical factors have strengthened the conditions for the other pillars of trust: the rule of law, a strong civil society and a sense of a shared destiny (Wollebæk, 2016).

We will now try to expand this historical explanation of the high level of trust in Norway by looking into the first crisis of modernity and comparing the analysis with the development in the rest of Scandinavia and then Spain.

\section{The first crisis of modernity}

A specific characteristic of 19th century European society was the limitations on freedom, depending on which social class or group one belonged to. There was a striking contradiction between the universal rhetoric regarding freedom, and the actual strong limitations on the freedom of the general population. The opportunities to express views and interests within the political system were limited to the elites who constituted a minority (Wagner, 1994). There was a liberal capitalism with individual autonomy for capitalists, without democracy and collective autonomy (Wagner, 2012).

The European working classes in the 19th century struggled to find their own social position under changing conditions. Prior to this period, they had been excluded from modernity processes, but were now able to define themselves in their own right, claiming a place in the newly emerging social order. This resulted in an awareness of social and economic inequalities and the emergence of ideologies promoting more equal income. Increasing rationality and the emergence of ideas concerning self-determination and autonomy then generated efforts to develop structures of collective action and mobilisation.

The first crisis of modernity emerged from these collective reorientations, as social movements and labour parties with various goals, as well as the rise of labour movements as institutions for negotiations and legitimate representatives for the workers, as collective answers to the social changes (Wagner, 1994; Trägårdh et al., 2013; Stråth and Wagner, 2017, p. 153). The limited liberal modernity of the 1800 s, with its contradictions and restrictions, could not be upheld any longer, and Western countries entered a social crisis, as new social groups were given the possibility of being a part of the modernisation of society (Wagner, 1994, p. 69). The industrial workers and the lower classes were now designated as the greatest threat and defined as the others. Concepts and notions such as proletariat and dangerous classes became part of the discourse and understanding in most industrialised European countries (Perrot, 1986, quoted from Wagner, 1994, p. 39).

The main goal of the reform movements in the latter half of the 19th century was to restore stability and predictability. Many of the established practices ceased and new institutions were to be built. The outcome was open, and there was considerable uncertainty as to whether a new consolidated order could be established (Wagner, 1994, pp. 57-59). Because of the economic dynamics in society, many considered it to be in the best interest of workers to organise themselves by class. Others believed it was a cultural predestination to bring together linguistic groups into political entities and make these entities the most important tool for resolving social tensions. Thus, the nation state was established as a phenomenon. 
Throughout the first half of the 20th century, societies were organised by class or nation - as the available concepts in the restoration of modernity - with more or less successful or disastrous outcomes (Wagner, 1994, p. 75, 2001, pp. 84-85).

The new form of social organisation emerged, mostly characterised by broader inclusion and "rational mastery" (Carleheden, 2010, p. 64), and, as Jürgen Habermas describes, as new regulations of the liberal market economy (Brown, 2017, p. 226). Organised modernity was initially characterised by specific features that made this project both feasible and, in the view of many actors, a desired goal. There existed consolidated institutions for material allocation, and authoritative power and significance at the national level. The interpretation of the negative aspects of societies had been widely accepted. It was agreed that the fundamental problem of the time was the integration of the masses, and that this task required new modes of social organisation (Wagner, 1994, p. 75) - to restore the institutions with greater or lesser public support and trust.

\section{The Norwegian reaction to the first crisis of modernisation}

A striking feature of the political culture in Norway at the turn of the 19th century was that the ongoing political nationalism was democratic and left-wing, limiting the polarisation between nationalism and political democracy (Sørensen and Brandal, 2018). The modernisation offensives of the bourgeois groups reached the consciousness of the industrial and agricultural workers towards the end of the 19th century in most of Europe, but earlier in the Scandinavian countries. General suffrage for men was introduced in Norway in 1898 and for women in 1913 (Sejersted, 2013, p. 73).

The common perceptions held in Norwegian society during this period were strengthened by the development of a common public-school system. This system constituted a type of democratic education that broke radically with the earlier parallel systems, which differentiated children according to social class (lower and higher classes). The idea behind the common school was to create schools that offered the same education throughout the country, where students from all the social classes could intermingle. The aim was to differentiate students as late as possible, and to provide everyone with equal access to higher education. However, the transition was a long process, taking place through the greater part of the 19th century and well into the 20th century.

Norway was the first country in Europe to introduce a five-years common public school for every child in 1896, while at the same time the requirement for knowledge in Latin, mostly taught at Cathedral schools, was removed as a requirement of admission to university. From 1920 onwards, Norway had compulsory education from the age of seven to fourteen, while most of the private schools that the bourgeoisie's children attended were purchased by the municipalities. This occurred during the period when the Liberal Party (Venstre) were in government; in other words, so-called class education was abolished by the introduction of common public schools in Norway by the Liberal government, long before the Social Democrats took over governmental power in 1935 (Sejersted, 2013, pp. 78-80).

The national sentiments during the first crisis of modernity emerged in Norway's struggle to liberate itself from the Union with Sweden, which was achieved in the dissolution of the union in 1905. The dissolution of the union created a more unified Norway, despite early internal struggles. There was widespread agreement in Norway, both before and after 1905, that the ideal was to have a limited foreign policy, consisting of a peace policy, free trade and neutrality (Knutsen et al., 2016, p. 96). The agreement on the position of the new state towards the rest of the world served as a solid foundation for meeting the new challenges that emerged in the early 20th century. The Norwegian Ministry of Foreign Affairs established a Press Office in 1909. All the political parties, including the social-democrats, liberals and conservatives, were involved in secret meetings, in order to establish this common tool to

\author{
Historical \\ accounts for \\ trust in \\ Scandinavia
}


CCIJ

26,1

promote Norwegian interests (Dahlen, 2017). Despite political divisions, this agreement created a more united society.

There were some revolutionary sentiments around 1920, and the Norwegian Labour Party was a member of the Soviet Comintern. When the established democratic system was however able to deal with acute revolutionary threats without the excessive use of physical force, this undermined possible support for political groups on the extreme left and right wings of the political spectrum. Consequently, the looming threat of revolution evaporated. Throughout the 1920s, most revolutionaries left their revolutionary positions and were integrated into the parliamentary democratic systems (Sørensen and Brandal, 2018, pp. 129-130).

There were demonstrations, strikes and class conflicts, but the conflicts were mainly handled in a peaceful manner by the authorities, and violent clashes were rare. The soft reaction towards strikers and protest may be linked to the basic policing philosophy. The Norwegian Ministry of Justice expressed the belief as early as 1866 that the esprit de corps of the Norwegian police should draw its inspiration from the English tradition of policing by consent, as this would counteract the kind of secret police that engages in covert operations and is associated with authoritarian states. This normative position can be traced back to the establishment of the Metropolitan Police in London in 1829 (the Metropolitan Police Act). The new police services aimed to develop a trustful relationship with the communities and people they served within the respective countries, so that people would have confidence in the police (Halvorsen, 2017, pp. 41-42; Ellefsen, 2015, p. 114). There were three basic features of this new model:

(1) The police should be unarmed: they should not carry firearms.

(2) Numerical inferiority in conflicts, making them depended on conflict-resolution without use of much violence.

(3) They should be publicly visible through the use of uniforms, but the colour and design of these should distinguish them from the uniforms of the armed forces. The public should always know when and in what situations the police were being used, which would be evident from the police's use of a recognisable uniform (Halvorsen, 2017, p. 41).

Thus, the police needed to have the consent of the public in order to perform their duties. As long as the police adopted moral-legal standards in the use of physical force based on normative standards and not on fear, this contributed to consolidating the role of the police as a stabilising force in society; and, in the long run, contributed to them being viewed as a genuine collective good, based on a constitutionally rooted social order (Halvorsen, 2017, p. 41), making them as a bridge between the government and its citizens at large and thus building trust.

In the 1930s, strikes and the use of strikebreakers in Norway were evidence that there were still conflicts within Norwegian society. However, workers' leaders did not view the trade unions as instruments of revolution, but rather as a means of ensuring workers' rights. A general strike in 1931 signalled an end to the conflict between capital and labour, since a closer cooperation was developed that eventually led to the establishment of the Basic Agreement, that is, collective bargaining between management and labour (Kjelstadli, 1994, pp. 183-187).

\section{The Swedish and Danish reactions to the first crisis of modernity}

Denmark and Sweden underwent many of the same historical developments as Norway in the current period. There was unrest and political protests and claims for democratic rights from 
both women, farmers and workers. The farmers in Denmark had joined the urban bourgeoisie in 1849 in a successful overthrow of the absolute rule, leading to a liberal constitution, inspired by the Norwegian counterpart, which was the start of the development towards democracy. Parliamentarism was established in Denmark in 1901, and women got the right to vote in 1915. In Sweden, 120,000 people went on strike for democratic rights in 1902, and 300,000 workers were on strike in 1909. Most men in Sweden got the right to vote in 1911, the king lost his political power in 1917, when parliamentarism was established, and Swedish women got the right to vote in 1921.

During the late 1920s, a number of security measures were implemented in the Scandinavian countries. Local labour unions were infiltrated, the government performed espionage on their leaders, and groups of secret conscripted soldiers were established to respond to revolutionary threats (Bergh and Eriksen, 1998, p. 33; Sørensen and Brandal, 2018, p. 25). Severe violent conflicts were however rare, and the police in Sweden and Denmark were also inspired directly by the English policing of consent philosophy (Ellefsen, 2015; Ellefsen and Larsson, 2014). No political murders or causalities were recorded in Scandinavia from 1880 to 1935.

The trade unions in Sweden and Denmark were not as revolutionary as their Norwegian counterparts and were therefore included earlier into the established political and parliamentary systems. The social-democratic parties were part of the Danish government in 1916 and the Swedish government in 1917. The school systems in Sweden and Denmark also had an early democratic ideology, with common public school from 1903 in Denmark and from 1919 in Sweden.

During the first crisis of modernity, the three Scandinavian countries went through a period of social and democratic reforms, based on dialogue and compromises. The people of the Scandinavian countries gave the all-encompassing states the responsibility for building the respective nations, with expanding developments reaching back to the early 19th century. Their welfare states were developed with a high degree of internal agreement between the various social classes (Kautto et al., 1999, pp. 1-14; Sejersted, 2013; Wollebæk, 2016).

The governments followed up the ambitions from the end of the 19th century by developing capitalism, democracy and social welfare. Thus, the governments averted the threat of totalitarian communist and fascist dictatorships that appeared in other European countries, while at the same time modifying the negative aspects of laissez-faire capitalism. The Scandinavian model found better answers to the crisis of modernity than unbridled capitalism and the totalitarian governments of the period. In the social democratic modernity project, state and society became more or less synonymous - they became interchangeable units (Sejersted, 2013; Slagstad, 2001; Vedung and Brandel, 2001).

\section{Spain as a comparative case}

Spain was plagued by conflicts between monarchists and republicans, and the rise and fall of different types of regimes in both the 19th and 20th century (Burns and Kamali, 2003, p. 263). The period between 1874, when Spain had a new constitution, and 1931, is known as the Restoration Period. The country had in this period a quasi-democracy, with a deliberate rotation of the Liberal and the Conservative parties in the government. All other parties were excluded by electoral fraud (Esdaike, 2000). Various governments did not manage to address the numerous injustices in Spanish society during this period or challenge the interests of the dominating oligarchy. There were attempts to introduce social improvements, but these efforts came from above, and not from the civil society (Esdaile, 2000; Salvadó, 1999, p. 153).

Spanish society in the late 1800s was characterised by huge differences between the rich and poor. Only $36 \%$ of the Spanish population were literate in 1900 (compared to nearly full literacy in Scandinavia). There were greatly diverging views regarding values, norms and

\section{Historical accounts for trust in Scandinavia}


CCIJ

26,1

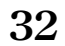

perceptions of how to solve societal challenges. Intellectual groups demanded solutions and improvements in education from the beginning of the 20th century, but there was still a greatly divided school system in the beginning of the 1930s, where approximately one million children still did not attend school at all (Flecha García, 2011). There were violent class struggles and internal conflicts regarding important political issues. Divergent opinions and the views of the trade unions were neither respected, nor met with counter arguments. Workers' protests and strikes were often met by the physical force of military troops, armed police and vicious reprisals. During these conflicts, civilians were imprisoned and killed, political leaders were executed after court martials, and the labour movement in Spain was repressed (Esdaile, 2000; Salvadó, 1999; Casanova and Andrés, 2014).

The Spanish political system was characterised by instability and corruption (Esdaile, 2000, p. 188). There was no continuous peaceful interaction over time where crucial issues could be discussed, or other common public platforms where divergent groups, and their representatives, could meet. The Spanish state was continually challenged by Catalan and Basque nationalists. The Spanish military carried out a reign of terror during the period against the Catalan press and anarchist movements were banned. Prime Minister Antonio Cánavas was killed by an anarchist in 1897, and Prime Minister José Canalejas was shot by another militant anarchist in 1912 (Esdaile, 2000; Salvadó, 1999; Casanova and Andrés, 2014).

The growing strength of labour movements and democracy did not succeed at the beginning of the century. Parliamentary democracy appeared to triumph in Spain in 1931 with republicans victorious, but 4,000 miners and civilians were killed by military troops and the police during the Asturian miners' strike of 1934 (Esdaile, 2000; Salvadó, 1999; Casanova and Andrés, 2014). The instability culminated in the 1936-1939 civil war (Burns and Kamali, 2003, p. 263).

\section{Trust in the first crisis of modernity}

In order to restore trust in society's institutions, the first crisis of modernity was in need of re-establishing clear conventions to increase the predictability of these institutions (Wagner, 2001, p. 83). We have seen how new institutions first tried to undermine the old institutions and arrangements, before restoring clear conventions and arrangements, as we have seen the labour movements as institutions for uprising in the first place and then negotiations and legitimate representation for the workers in Scandinavia. Most members of the community experienced these transformations as something that came from outside, something that one could try to defend against, but not something that one could shape or influence (cf. Wagner, 2001, p. 83). Thus, it is first and foremost the governments' responsibility to include the population and restore the predictability of the main institutions.

In research question 1, we asked what the main historical factors are, related to the reactions to public complaints and divergent opinions during the first crisis of modernity, that can explain the high level of trust in Scandinavia. Continuous interaction is one of the four main historical factors explaining the level of trust in a society (point 4 in Table 1), presented earlier in this article. The possibilities for making changes in society by non-violent means (e.g. PR) are often dependent on how the state uses physical force. Established society could meet divergent opinions and revolutionary threats in two ways. One is by using what we can call an iron fist strategy, that is, by using armed police to stop protests and imprison protesters. The other is by using what we can call an open hands strategy, that is, including the deviating opinions of the workers and their movements and initiating reforms and making compromises with the labour movement. The police forces in Scandinavia were built on an ideology of consent, in order to build trust between the government and citizen, long before Edward L. Bernays (1947) introduced "The Engineering of Consent" phrase to the US business world. 
In spite of the fear of revolution and the security measures, the dominant political response towards workers in Scandinavia was definitely an open hands strategy (Sørensen and Brandal, 2018, p. 25). Tolerance for the expression of left- or right-wing viewpoints strengthened the possibilities for dialogue and compromises. Policing by consent supported this gradual development of an open, democratic society in Scandinavia and made possible peaceful transitions of power between the social classes - and then establishing an all-encompassing nation-state as the main, all-including institution in society, without repression and total control. This was supported by the common school system, in which national sentiments, as a purposive strategy, was an important part - and the political cooperation above party lines, with the governmental co-operation in Sweden and Denmark, and the Ministry of Foreign Affairs Press Office in Norway from 1909.

The transition into modern societies during this period generally followed a relatively peaceful pattern in Scandinavia, with the development of independence, democracy and the establishment of civil institutions, based on dialogue, agreements and compromises (Sørensen and Brandal, 2018, p. 8), rather than armed conflicts, revolutions or civil wars. And thus, making room for common public attention, competition in society, a public sphere, public debate and opportunities to exert influence, being necessary conditions for PR activities (cf. Bentele, 2015, p. 29). It is therefore reasonable to believe that the practice of public relations, as an alternative to the use of physical force (cf. Bentele, 2015, p. 26), played a crucial role in this development towards trust between the governments and its citizens.

Algan and Cahuc (2010) suggest that the rise of trust in Denmark and Sweden at the beginning of the 20th century can be explained by the manner in which the authorities ended labour conflicts and created welfare states. They point out that "Sweden was marked in the early 1900 s by a world record for days lost in labour disputes and strong class conflicts" (Algan and Cahuc, 2010, p. 2069). This suggests that there was a low level of generalised trust, but we will point out that this shows that there was a climate where protest was allowed, because of the relatively high level of trust between the classes. These open hands policies and agreements between the parties eventually ended the dramatic labour conflicts and led to the compromises and establishment of welfare states that enabled trust to be restored.

We will suggest that many observers exaggerate the political conflicts of the beginning of the century in Scandinavia. There were conflicts and disagreements, but there was also a high level of trust between the three main modern social systems: the state, trade and industry, and civil society; between the governments, industrial owners and trade unions. There was extensive co-operation between representatives of the different classes within the national states and between the governments and the unions - and the labour conflicts were relatively peacefully handled by the authorities (cf. the police of consent ideology), compared to other

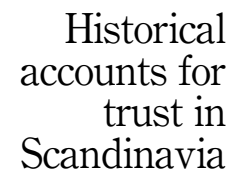

33
Factors explaining trust Scandinavia, 1890-1935 Spain, 1890-1935

(1) A fair legal system and A fair legal system and little little corruption

(2) Equality: economic, values and norms

(3) Common perception of destiny, facts and challenges

(4) Interaction, dialogue and a respected civil society corruption. Open political decisionmaking processes

A gradual development towards equality

National consensus on the main strategies and goals

Peaceful interaction, democracy, freedom of speech, tolerance of different viewpoints. Compromises
A corrupted legal system. Closed

political decision-making processes

Lack of equality or development towards equality

National divides and severe class conflicts

Violent conflicts over political disagreements. Imprisonment and death trails against divergent opinions
Table 1.

Historical factors explaining the level of trust in Scandinavia and Spain, 1890-1935 
CCIJ

26,1

34

countries in Europe, such as Spain. There were crises and conflicts in all European countries, but the crises in Scandinavia were resolved through dialogue and co-operation within the common institution, the nation state.

In research question 2, we asked what the main historical factors are, related to the reactions to public complaints and deviating opinions during the first crisis of modernity, that can explain the relatively low level of trust in Spain. There are striking differences between how the Spanish authorities reacted to people's wishes to be a part of the state and modern society during the first crisis of modernity, compared to the Scandinavian authorities. In the transition between a liberal and organised modernity, new institutions were formed in both Spain and Scandinavia, first and foremost representatives of the workers.

In Spain, the workers' organisations were not respected or included, and large sections of the population were still kept out of the organisation of the nation state and its organising institutions, as the political and educational institutions. There was no fair legal system, a lot of corruption, no economic and cultural equality, a divided perception on facts and challenges, no continuous interactions, no respected civil society and little respect for protests and divergent opinions. When the Scandinavian countries organised the society within a common institutional (national) structure, Spanish society was still divided by severe class conflicts, hindering continuous interactions (cf. point 4 in Table 1). This was a process that developed into the 1936-1939 civil war, leading to a sort of dictatorially organised modernity. The nation state was institutionalised under gross repression and total control, lasting until 1975.

Within Spain there were greatly diverging views regarding values and norms, which contradicts point 2 in Table 1 . A change in the social order was not a desired goal for those in power in Spain, and perceptions of how to meet the challenges of the first crisis of modernity and the interpretations of the negative aspects of the current situation in Spain were not widely accepted (cf. Wagner, 1994, p. 75) which contradicts point 3 (see Table 1). There were no significant institutions for material distribution on a national level. And it was not agreed that the fundamental problem of the time was the integration of the masses, and that this task required new forms of social organisation (cf. Wagner, 1994, p. 75). There was a development through a common identity as an industrial worker, but their fight for a full place in society was almost impossible. The transformations of society came from above without much concern for the masses. Although there was a degree of parliamentarism in Spain, the decision-making processes were not very democratic or transparent, and, unlike the Scandinavian parliamentary-corporative system, the Spanish political system was characterised by instability and corruption, which contradicts point 1 (see Table 1).

In research question 3, we asked how governmental conflict resolution during the first crisis of modernity could support and expand our understanding of the level of institutional and social trust. Workers' protests and strikes in Scandinavia were often met with reforms and the adoption of laws benefiting the workers, while protests in Spain were met by the physical force of military troops, armed police and vicious reprisals from the police and the military, in order to stop and hinder the population from having their say in the public sphere and to protest against unjust conditions. During the period of 1890-1935, there were no political assassinations in Scandinavia, whereas during the same period in Spain, two prime ministers were shot, and military troops and the police killed strikers and other civilians. The representatives of the labour movement in Spain were repressed by the government, unlike in Scandinavia, where the social democrats, socialists and communists were incorporated into common (national) democratic institutions.

The governments in the countries in question tried to make the nation state the main institutional principle. The Scandinavian countries, however, allowed the workers to organise themselves as workers inside the main institution, the nation state. They allowed the workers to develop their own identity, but gradually included them into the national parliamentary 
system; not by use of violence but by showing them that the political system was a useful tool for all classes and interests, creating a more trustful relationship.

This open hand strategy was based on a democratic and liberal political development and a policing by consent ideology. Edward Bernays emphasised that "any person or organization depends ultimately on public approval and is therefore faced with the problem of engineering the public's consent to a program or goal" (1947). This strategy can be easily transformed into governmental relations in general and especially the policing by consent ideology. The main organising concept of modernity in the Scandinavian countries was the all-including nation states, where class had a lesser important role. Spain by contrast remained very much a class society after the first crisis of modernity, and the state was split into various nations, and especially the Catalans and the Basques were asking (and fighting) for a more independent status. We have therefore good reasons to believe that the people of Scandinavia mostly trusted the governmental institutions at the beginning of the 1930s, whereas the mistrust in Spain led to the civil war from 1936.

The comparison between Scandinavia and Spain can in first place seem quite unfair, because of the unequal starting points in 1890. The different starting points can however strengthen the factors presented in Table 1: a fair legal system, a minimum of corruption, economic and cultural equality, common perception on facts and challenges, continuous interactions, a respected civil society and - as we have specially noted in this article - the choice of the nation-state as the main and inclusive container of other institutions, and the respect for protests and deviating opinions, to the extent that they are not imprisoned and refused a place in the market place of ideas, as John Stuart Mill put it (Bilgrami, 2009).

\section{Class or nation as the main organising concept}

The politicians in power have responsibility for governing public institutions, the legal system, social welfare, market regulations and so on, all of which depend on public trust if they are to function well. As democracy requires a certain type of scepticism towards politics (cf. Inglehart, 1999), there must be a room for political debate. Jurgen Habermas (1998) pointed out that democratic processes are the most important guarantor of social integration in modern society: when citizens perceive themselves as the authors of the law, they will feel strongly socially engaged, thus maintaining social integration and upholding a relationship of trust with those in power. The citizens, or their representatives, need institutions for communication, where they can promote new solutions, while criticising and condemning the old.

There seems to be a strong connection between conflict management on a national level and the question of maintaining trust, both in governments and institutions and also in relation to general social trust. Alternatively, the connection can be seen the other way around: general trust in a society is an important foundation to meet threats and demands with an open hands strategy, as to be trusted can both be a means and an end for public relation assessment (cf. Ihlen et al., 2018, p. 422).

We have pointed out two important factors from the first crisis of modernity that may explain the high level of trust in Scandinavia and the relatively low degree of trust in Spain. Both point to the already established factor (see point no. 4 in Table 1) of interaction, dialogue and a respected civil society:

(1) The establishment of the nation state as the organising concept and all-encompassing container of the other institutions (democracy, parliamentarism, trade unions, etc.).

(2) The open hand strategy in dealing with deviating opinions, based on democratic compromises and a policing of consent ideology.

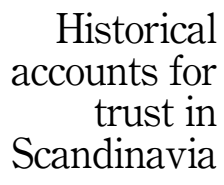

35 
CCIJ

26,1

This policing by consent ideology can definitely be seen as an early governmental public relation strategy, in order to legitimate (cf. Lamme and Russel, 2009) the monopoly of violence. Being unarmed and in numerical inferiority is a way to show an interest in communication and finding peaceful solutions. The uniforms also show who they are representing (the state), and the public and opinion will know how the police treat people with deviating opinions, which can also be seen as an invitation to debate in the public sphere on the role of the police, and could help to reduce the suspicion of corruption in government, making room for PR activities (cf. Bentele, 2015; Lamme and Russel, 2009; Russel and Lamme, 2013).

As the nation state is the main container of other institutions, governmental institutions have to prove that they are able to justify their acts in front of the population (through both action and communication), but also be able to listen to critique and to adjust their actions in order to maintain trust. The alternative is to divide the society into different classes, hindering the necessary dialogue between different segments of the population, as we have seen that the demands and protests in Spain were met by an iron fist. The Spanish attempt to restore social order and discipline during the period led to punishment, violence and mistrust between the various groups.

The choice between the nation state or class, as the available concepts in the restoration of modernity, seems to be of uppermost importance for establishing stability, predictability and dialogue - and therefore trust in society's institutions. It seems that the core of the development of governmental trust through the first crisis of modernity lies in this choice, establishing conflict or unity, bringing the masses into the nation state or not. The establishment of the nation state and the open hand strategy during the first crisis of modernity can therefore expand our understanding of the development of trust, in addition to the four factors emphasised in Table 1. More research could determine if this could serve as a general (or global) historical explanation of trust.

\section{Notes}

1. https://www.europeansocialsurvey.org

2. http://www.worldvaluessurvey.org/wvs.jsp

\section{References}

Algan, Y. and Cahuc, P. (2010), "Inherited trust and growth", The American Economic Review, Vol. 100 No. 5, pp. 2060-2092.

Bentele, G. (2015), "Problems of public relations historiography and perspectives of a functionalintegrative model", in Watson, T. (Ed.), Perspectives on Public Relations Historiography and Historical Theorization, Palgrave Macmillan, Basingstoke, pp. 20-47.

Bergh, A. and Bjørnskov, C. (2011), "Historical trust levels predict the current size of the welfare state", Kyklos, Vol. 64 No. 1, pp. 1-19.

Bergh, T. and Eriksen, K.E. (1998), Den hemmelige krigen. Overvåkning i Norge 1914-1997. Vol. 1: Overvåkningssystemet bygges opp 1914-1955, Cappelen Akademisk Forlag, Oslo.

Bernays, E.L. (1947), "The engineering of consent", The Annals of the American Academy of Political and Social Science, Vol. 250 No. 1, pp. 113-120.

Bilgrami, A. (2009), “Truth, balance, and freedom”, Social Research, Vol. 76 No. 2, pp. 417-436.

Brown, C. (2017), Habermas and Giddens on Praxis and Modernity. A Constructive Comparison, Anthem Press, London.

Burns, T.R. and Kamali, M. (2003), "The evolution of parliaments: a comparative-historical perspective on assemblies and political decision-making", in Delanty, G. and Isin, E.F. (Eds), The Handbook of Historical Sociology, Sage, London, pp. 261-275. 
Carleheden, M. (2010), "The imaginary signification of modernity: a re-examination", Distinktion: Scandinavian Journal of Social Theory, Vol. 11 No. 2, pp. 51-70.

Casanova, J. and Andrés, C.G. (2014), Twentieth-Century Spain. A History, Cambridge University Press, Cambridge.

Dahlen, Ø. (2017), "UDs hemmelige pressekontor”, Mediehistorisk tidsskrift, Vol. 14 No. 27, pp. 18-41.

Dahlen, Ø. (2019), "Modernity and the development of PR in Norway: influences and interactions", Public Relation Review, Vol. 45 No. 2, pp. 192-201.

Delanty, G. and Isin, E.F. (2003), "Introduction: reorienting historical sociology", in Delanty, G. and Isin, E.F. (Eds), The Handbook of Historical Sociology, Sage, London, pp. 1-8.

Edwards, L. (2018), Understanding Public Relations. Theory, Culture, Society, Sage, London.

Ellefsen, B. (2015), "The making of a new police: an analysis of the Norwegian police discourse 1814-1866", in Granér, R. and Konkvist, O. (Eds), The Past, the Present and the Future of Police Research. Proceedings from the Fifth Nordic Police Research Seminar, Linneæus University.

Ellefsen, B. and Larsson, P. (2014), "Skandinavisk politihistorie”, in Larsson, P., Ingebrigtsen, H.O. and Granér, R. (Eds), Innføring i politivitenskap, Cappelen Damm, Oslo.

Esdaile, C.J. (2000), Spain in the Liberal Age. From Constitution to Civil War, 1808-1939, Blackwell Publishers, London.

Flecha García, C. (2011), "Education in Spain: close-up of its history in the 20th century", Analytical Reports in International Education, Vol. 4 No. 1, pp. 17-42.

Gambetta, D. (1988), Trust. Making and Breaking Cooperative Relations, Basil Blackwell, New York.

Giddens, A. (1990), The Consequences of Modernity, Polity Press, Cambridge.

Grimen, H. (2009), Hva er tillit?, Universitetsforlaget, Oslo.

Habermas, J. (1996), Between Facts and Norms. Contribution to a Discourse Theory of Law and Democracy, Polity Press, Cambridge.

Habermas, J. (1998), The Inclusion of the Other. Studies in Political Theory, Polity Press, Cambridge.

Halvorsen, V. (2017), “«Politihistorie»”, NOU, 2017:9, in Politi og bevapning. Legalitet, nødvendighet, forholdsmessighet og ansvarlighet, Norwegian Government Security and Service Organisation, Oslo, pp. 41-47.

Hu, B., Huang, Y.H. and Zhang, D. (2015), "Public relations and Chinese modernity: a 21st-century perspective", Journal of Public Relation Research, Vol. 27 No. 3, pp. 262-279.

Ihlen, Ø. and Verhoeven, P. (2012), “A public relations identity for 2010s”, Public Relations Inquiry, Vol. 1 No. 2, pp. 159-176.

Ihlen, Ø., Verhoeven, P. and Fredriksson, M. (2018), "Conclusions on the compass, context, concepts, concerns and empirical avenues of public relations", in Ihlen, Ø. and Fredriksson, M. (Eds), Public Relations and Social Theory. Key Figures, Concepts and Developments, 2nd ed., Routledge, London, pp. 414-431.

Inglehart, R. (1999), "Trust, well-being and democracy", in Warren, M.E. (Ed.), Democracy and Trust, Cambridge University Press, pp. 88-120.

Kautto, M., Heikkiliä, M., Hvinden, B., Marklund, S. and Ploug, N. (1999), Nordic Social Policy, Routledge, London.

Kjelstadli, K. (1994), "Et splittet samfunn. 1905-35”, in Helle, K. (Ed.), Aschehoug's History of Norway, Vol. 10, Aschehoug, Oslo.

Knutsen, T.L., Leira, H. and Neumann, I.B. (2016), Norsk utenrikspolitisk historie, Universitetsforlaget, Oslo.

Lamme, M.O. and Russell, K.M. (2009), "Removing the spin: toward a new theory of public relations history”, Journalism and Communication Monographs, Vol. 11 No. 4, pp. 280-362.

\section{Historical accounts for trust in Scandinavia}


CCIJ 26,1

L'Etang, J. (2008), "Writing PR history: issues, methods and politics", Journal of Communication Management, Vol. 12 No. 4, pp. 319-335.

Perrot, M. (1986), "On the formation of the French working class", in Katznelson, I. and Zolberg, A.R. (Eds), Working-Class Formation, Nineteenth-Century Patterns in Europe and the United States, Princeton University Press, Princeton, pp. 71-110.

Putnam, R.D. (2000), Bowling Alone. The Collapse and Revival of American Community, Simon and Schuster Paperbacks, London.

Rothstein, B. (2013), "Corruption and social trust: why the fish rots from the head down", Social Research, Vol. 80 No. 4, pp. 1009-1032.

Rothstein, B. and Uslaner, E.M. (2005), "All for all. Equality, corruption, and social trust", World Politics, Vol. 58 No. 1, pp. 41-72.

Russel, K.M. and Lamme, M.O. (2013), "Public relations and business responses to the civil rights movement”, Public Relations Review, Vol. 39, pp. 63-73.

Salvadó, F.J.R. (1999), Between War and Revolution, Routledge, London.

Sejersted, F. (2013), Sosialdemokratiets tidsalder. Norge og Sverige i det 20. århundre, Pax Forlag, Oslo.

Skirbekk, H., Middelthon, A.-L., Hjortdahl, P. and Finset, A. (2011), "Mandates of trust in the doctorpatient relationship", Qualitative Health Research, Vol. 21 No. 9, pp. 1182-1190.

Skirbekk, H. and Skirbekk, G. (2012), "Tillit og mistillit. Norge og Sicilia”, in Skirbekk, H. and Grimen, H. (Eds), Tillit i Norge, Pax Publica, Oslo.

Skocpol, T. and Somers, M. (1980), "The uses of comparative history in macrosocial inquiry", Comparative Studies in Society and History, Vol. 2 No. 2, pp. 174-197.

Slagstad, R. (2001), De Nasjonale strateger, Pax Forlag, Oslo.

Sönderskov, K.M. and Dinesen, P.T. (2016), "Trusting the state, trusting each other? The effect of institutional trust on social trust", Political Behavior, Vol. 38 No. 1, pp. 179-202.

Sørensen, Ø. and Brandal, N. (2018), Det norske demokratiet og dets fiender. 1918-2018 [The Norwegian Democracy and Its Enemies. 1918-2018], Dreyers forlag, Oslo.

Stråth, B. and Wagner, P. (2017), European Modernity. A Global Approach, Bloomsbury, London.

Trägårdh, L., Lundåsen, S.W., Wollebæk, D. and Svedberg, L. (2013), Den svala svenske tilliten. Förutsätningar och utmaningar, SNS Förlag, Stockholm.

Tschannen-Moran, M. and Hoy, W.K. (2000), "A multidisciplinary analysis of the nature, meaning, and measurement of trust", Review of Educational Research, Vol. 70 No. 4, pp. 547-593.

Vedung, E. and Brandel, M. (2001), Vattenkraften, staten och de politiske partierne, Bokförlaget Nya Doxa, Falun.

Wagner, P. (1994), A Sociology of Modernity. Liberty and Discipline, Routledge, London.

Wagner, P. (2001), A History and Theory of the Social Sciences, Sage, London.

Wagner, P. (2003), "As intellectual history meets historical sociology: historical sociology after the linguistic turn", in Delanty, G. and Isin, E.F. (Eds), The Handbook of Historical Sociology, Sage, London, pp. 168-179.

Wagner, P. (2008), Modernity as Experience and Interpretation. A New Sociology of Modernity, Polity Press, Cambridge.

Wagner, P. (2012), Modernity. Understanding the Present, Polity Press, Cambridge.

Wollebæk, D. (2016), “Tillit under press”, Syn og Segn, No. 3, pp. 44-51.

\section{Further reading}

Delanty, G. (2018), “The historical regions of Europe: civilizational backgrounds and multiple routes to modernity", Historická Sociologie, Vol. 4 No. 1, pp. 9-24. 
Luoma-aho, V. (2018), "On putnam: community and social capital”, in Ihlen, Ø. and Fredriksson, M. (Eds), Public Relations and Social Theory. Key Figures, Concepts and Developments, 2nd ed., Routledge, London, pp. 195-214.

Torcal, M. (2014), "The decline of political trust in Spain and Portugal: economic performance or political responsiveness?", American Behavioral Scientist, Vol. 58 No. 12, pp. 1542-1567.

Historical
accounts for
trust in
Scandinavia

Wagner, P. (2015), "From domination to autonomy: two eras of progress in world-sociological perspective", Historická Sociologie, Vol. 7 No. 2, pp. 27-44.

\section{About the authors}

Øystein Pedersen Dahlen; Sociologist. CandPolit, CandMag. 2011-: Senior Lecture, Kristiania University College. 2003-2010: Teacher, Volda University College. 1993-2002: PR consultant and manager. Øystein Pedersen Dahlen is the corresponding author and can be contacted at: oystein.dahlen@kristiania.no

Helge Skirbekk; Medical sociologist. PhD, CandPolit, CandMag. 2017-: Associate professor, University of Oslo. 2015-: Associate professor, Lovisenberg Diaconal College. 2014-2015: Senior researcher, NK LMH. 2012-2013: Associate professor, Kristiania University College.

For instructions on how to order reprints of this article, please visit our website:

www.emeraldgrouppublishing.com/licensing/reprints.htm

Or contact us for further details: permissions@emeraldinsight.com 